\title{
Low level of physical fitness is an early feature in preschool children with autism El nivel bajo de la aptitud física es una característica temprana en niños preescolares con autismo
}

*Pedro Ángel Latorre-Román, *Míriam Sánchez-Salvador, **Jesús Salas-Sánchez, ***Felipe García-Pinillos *Universidad de Jaén (España), **Universidad Autónoma de Chile (Chile), ***Universidad de La Frontera, Temuco (Chile)

\begin{abstract}
Background: Physical fitness level is a potent biomarker of health from an early age. Physical activity and Physical fitness have a similar influence on health outcomes including overweight. However, Physical activity and Physical fitness in children with autism spectrum disorders have received little attention. The purpose of this study was to evaluate physical fitness in preschool children with ASD. Methods: A total of 31 children, aged 3 to 6 years, participated in this study: 13 children with ASD (Age=50.23 \pm 7.62 months, 2 girls and 11boys) and 18 children without ASD (Age=51.33 \pm 11.06 months, 4 girls and 14 boys). A fitness test battery was employed. Results: Children with ASD have lower performance in physical fitness tests. However, no significant differences were found in anthropometrics characteristics, physical activity time, screen-based time and physical functioning. Conclusions: Preschoolers with ASD show an early deterioration in physical fitness. Physical activity programs at pre-school level are necessary to stimulate these abilities in children with ASD.
\end{abstract}

Keywords: preschool children, neurodevelopmental disorders, fitness, physical activity.

Resumen. Objetivo: El nivel de condición física es un biomarcador potente de la salud desde una edad temprana. La actividad física y la aptitud física tienen una influencia similar en la salud, incluyendo el sobrepeso. Sin embargo, el estudio de la actividad física y de la condición física en niños con trastornos del espectro autista (TEA) ha recibido poca atención. El propósito de este estudio fue evaluar la condición física en niños en edad preescolar con TEA. Métodos: En este estudio participaron 31 niños de 3 a 6 años de edad: 13 niños con TEA (edad = 50,23 \pm 7,62 meses, 2 niñas y 11 niños) y 18 niños sin TEA (edad = 51,33 \pm 11,06 meses, 4 niñas y 14 niños). Una batería de condición física para niños preescolares fue empleada. Resultados: Los niños con TEA tienen menor rendimiento en las pruebas de condición física. Sin embargo, no se encontraron diferencias significativas en las características antropométricas, tiempo de actividad física, tiempo de uso de pantallas y el funcionamiento físico. Conclusiones: Los niños en edad preescolar con TEA tienen un deterioro temprano en la condición física. Los programas de actividad física a nivel preescolar son necesarios para estimular estas capacidades en niños con TEA.

Palabras clave: niños preescolares, autismo, fitness, actividad física.

\section{Introduction}

Physical fitness (PF) level is a potent biomarker of health from an early age(Ortega, Ruiz, Castillo \& Sjöström, 2008). Moreover, physical activity(PA) and PF have a similar influence on health outcomes including overweight (Rauner, Mess \& Woll, 2013). However, PA and PF in children with autism spectrum disorders (ASDs) have received little attention. In addition, children with ASD may be at increased risk for overweight and obesity (Dreyer Gillette etal., 2015), but littleinformation is known about correlates of overweight and obesity in preschool children with ASD in relation to PA, PF and sedentary behaviour.

A scarce number of studies suggest that PA may be especially beneficial to children with ASD including improved of physical, physiological, psychological and behavioural functioning (Dickinson \& Place, 2014; Pan, 2011; Sorensen \& Zarrett, 2014).

The preschool years are characterized by significant changes in the acquisition of locomotors, object control skills and nervous system maturation (Tanaka, Hikihara, Ohkawara \& Tanaka, 2012). Although the differences in motor development are not considered primary diagnostic categories for ASD (Lai, Lombardo, \& Baron-Cohen,2014; Pan, 2011), various studies have indicated that the movement skills of children with ASD reflect deficits (Staples \& Reid, 2010), and they showed lower PF and PA than children without disabilities (Pan, 2011; Tyler, MacDonald \& Menear, 2014). In this regards, individuals with low motor competence had less optimal levels of overall health and fitness indices than those with high motor competence (Cantell, Crawford \& Tish Doyle-Baker, 2008).

Many of the studies on PA in children with ASD have focused on children above 7 years old (Sorensen \& Zarrett, 2014); therefore, little research on preschool children (Bandini et al., 2013; MacDonald, Lord \& Ulrich, 2014) was found. Considering the facts and information mentioned above, the purpose of this study is to analyse the anthropometric characteristics, PF, PA and sedentary behaviour in preschool children with ASD.

Fecha recepción: 03-05-17. Fecha de aceptación: 22-11-18 Jecús Salas Sánchez

jesussalas644@gmail.com

\section{Material and method}

\section{Participants}

A total of 31 children, aged 3 to 6 years, participated in this study: 13 children with ASD (Age $=50.23 \pm 7.62$ months, 2 girls and 11 boys) and 18 children without ASD (Age=51.33 \pm 11.06 months, 4 girls and 14 boys). Diagnoses of ASD were obtained by a trained clinical psychologist based on DSM-IV (American Psychiatric Association, 2000), the Autism Diagnostic Interview-R (Catherine Lord, Rutter \& Le Couteur, 1994) and the Autism Diagnostic Observation Schedule (Lord et al., 2000). Participants were recruited via local schools and the local association of autism. Inclusion criteria were: to be in good health and free from diseases or disorders that could affect PA (e.g., diabetes, asthma), moreover, exclusion criteria was: show no verbal skills to communicate with the researchers. Parents voluntarily signed an informed consent form for the participation of their children in this study. The study was completed in accordance with the norms of the Declaration of Helsinki (2013 version). The study was approved by Ethics Committee of the University of Jaen (Jaen, Spain).

\section{Materials and testing}

Height $(\mathrm{cm})$ was measured with a stadiometer(Seca 222, Hamburg, Germany) and weight (Kg) with a bascule (Seca 899, Hamburg, Germany). Body mass index (BMI) was calculated by dividing weight (in kilograms) by height ${ }^{2}(\mathrm{~m})$. Waist circumference(WC) was measured by using a SECA Ergonomic Circumference Measuring Tape SE201 (SECA, Germany). Moreover, we used the fitness test battery by Latorre et al. (2015), which is focused on testing basic components of $\mathrm{PF}$, such as endurance (10 x $20 \mathrm{~m}$ ), strength (standing broad jump), sprint (20 m) and balance (flamingo). Additionally, handgrip strength was assessed by manual dynamometer (electronic hand dynamometer, model: EH101). Physical activity time and screen-based time were registered by parental report using the Krece Plus questionnaire (Serra Majem, Aranceta Bartronaq, Ribas Barba, Sangil Monroy, \& Pérez Rodrigo, 2003). Physical functioning was registered by factor 1 of the Pediatric Quality of Life Inventory in its Spanish version (GonzálezGil et al., 2012) which is composed of 21 items comprising 4 dimensions: Physical functioning, Emotional functioning, Social functioning and School functioning. Physical functioning is composed by 8 items scoring of 5-point Liker scale from 0 (Never) to 4 (Almost always). 


\section{Procedure}

In three separate sessions, a team of previously trained researchers performed the evaluation. In the first testing session, handgrip strength (two trials of each hand, left and right'; the average of both hands was registered), the standing broad jump test (two trials, the best trial was registered) and the balance test (two trials with left and right leg; the average of both legs was registered) were performed. Two-days later, the $20 \mathrm{~m}$ sprint (two trials, the best trial was registered) and $10 \mathrm{x} 20 \mathrm{~m}$ tests (one trial) were performed. Prior to the testing sessions, children performed a typical warm-up consisting of 5 minutes of low-intensity running, and 5 minutes of general exercises (high skipping, leg ûexions, lateral running, front and behind arm rotation, and sprints). The children also performed some familiarization trials for the balance assessment and the horizontal jumping. Each child was individually assessed. The research team conducted a demonstration. The children were motivated and encouraged to reach the best score possible in every test.

\section{Statistical Analysis.}

Data were analysed using SPSS v.19.0 for Windows (SPSS Inc., Chicago, U.S.A.) and the significance level was set at $\mathrm{p}<0.05$. The data are shown in descriptive statistics for mean and standard deviation (SD). Tests of normal distribution and homogeneity (KolmogorovSmirnov and Levene's respectively) were conducted on all data before analysis. Differences between children withASD and children without ASD were analysed using analysis of variance (ANOVA).

\section{Results}

Table 1 shows the anthropometric variables. There are no significant differences between the two groups of children in any of the variables analysed. Physical fitness, PA time, screen-based time and physical functioning are shown in Table 2. Children with ASD have lower performance in all PF tests. However, no significant differences were found in PA time, screen-based time and physical functioning.

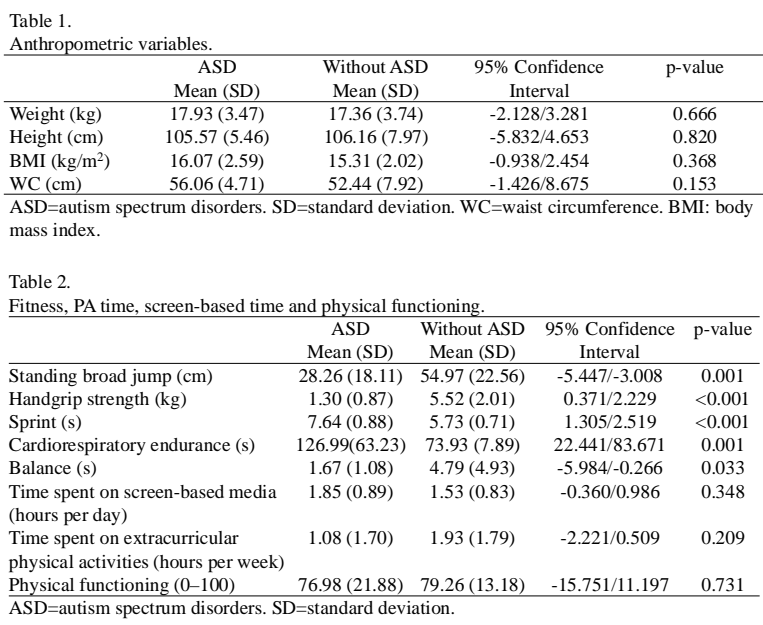

\section{Discussion}

The aim of this study was to analyse anthropometric characteristics, PF, PA and sedentary behaviour in preschool children with ASD. The most important finding of this study was that preschool children with ASD showed worse PF than children without ASD. Moreover, nonsignificant differences were found in relation to anthropometrics characteristics, PA time, screen-based time and physical functioning.

Considering anthropometric variables, as for the BMI, children with ASD are located in approximately the 50th percentile and the group without ASD in the 25th percentile (Carrascosa Lezcano et al., 2008), which is a state of normal weight. Previous studies on children with ASD at school age have not found significant differences in anthropometric variables from children with typical development (Sandt \& Frey, 2005; Tyler et al., 2014). Nevertheless, de Vinck-Baroody et al.
(2015) showed that the prevalence of overweight and obesity in children with ASD was $33.9 \%$ and $18.2 \%$, respectively; therefore, ASD was associated with a higher risk of obesity (but not overweight). Moreover, Niederer et al. (2012) showed association between BMI and fitness level in preschool children. In this regards, Okely, Booth and Chey (2004) noted that BMI and WC were significant predictors of fundamental motor skills in children and adolescents. In relation to WC, clinical cut-offs used to determine abnormal levels were: waiste»90th percentile for age and sex (Fernandez, Redden, Pietrobelli, \& Allison, 2004). In the current study, neither the children with ASD nor those without ASD showed abnormal levels of waist circumference (Maffeis, Pietrobelli, Grezzani, Provera \& Tatò, 2001). Finally, in accordance with Kondri et al. (2013), this study found no association between BMI, WC and PF.

On the other hand, in the current study, there were no significant differences in time employed with screen-based media, physical functioning and time of PA between children with ASD and typical development. However, Mazurek and Wenstrup (2013) showed that children with ASD spent more hours per day playing video games compared with their typically developing siblings'. Moreover, Gillett et al. (2015) specified that children with ASD engaged in PA less than children without ASD; however, no differences were found in most measures of screen time. In this regards, Bandini et al. (2013) showed that children with ASD have similar levels to typically developing children in PA registered by accelerometry; nevertheless, analysing the information through parental report, children with ASD are involved in fewer PA.

In relation to $\mathrm{PF}$, a previous study in children with ASD revealed that they showed worse performance in handgrip strength and flexibility tests, but not in aerobic capacity (Tyler et al., 2014). In this regard, Kern et al. (2013) indicated that handgrip strength in children with ASD was significantly lower than children without ASD; so, children with ASD have muscle weakness, and the results provide support for the use of handgrip strength as a tool for the assessment of targeted treatment in ASD. Other researchers revealed that, in children with ASD, the movement skills and motor development deficits also reflect delays (Provost, Lopez \& Heimerl, 2007; Staples \& Reid, 2010). Likewise, Pace \& Bricout (2015) found that children with ASD exhibit lower PF than peers with typical development; specifically, showed lower results on the plate tapping test, vertical and broad jump tests, sit up test, flamingo balance test, handgrip strength and heart rate response.

Although the physical-motor condition is not considered a primary diagnostic category of ASD, in this study we found significant deterioration of PF in preschool children with ASD. The clinical implications of these findings suggest that preschool children with ASD should receive full development assessments including the evaluation of PF to promote health, prevent overweight and obesity.

One limitation of this study is the small number of subjects analysed. Another limitation of the present study is its cross-sectional design; so caution must be exercised when interpreting the observed associations. More studies are needed to provide adequate evidence of causality. However, this is a novel study since it is focused on a very special population: preschool-aged children with ASD. New studies should advance understanding of the associations with physical-motor condition in children with ASD, establishing in turn possible differences between sexes and analysing the possible predictive capacity of PF in ASD in early age.

\section{Conclussions}

In conclusion, pre-schoolers with ASD showde a significant deterioration in PF. Physical activity programmes at pre-school level are necessary to stimulate these abilities in children with ASD.

\section{References}

American Psychiatric Association. (2000). Diagnostic and Statistical 
Manual of Mental Disorders, Fourth Edition, Text Revision (DSMIV-TR). Text (Vol. 1). doi:10.1176/appi.books.9780890423349.

Bandini, L. G, Gleason, J., Curtin, C., Lividini, K., Anderson, S. E., Cermak, S.A, ... Must,A. (2013). Comparison of physical activity between children with autism spectrum disorders and typically developing children. Autism/: The International Journal of Research and Practice, 17(1), 44-54. doi:10.1177/1362361312437416.

Cantell, M., Crawford, S. G., \& Tish Doyle-Baker, P. K. (2008). Physical fitness and health indices in children, adolescents and adults with high or low motor competence. Human Movement Science, 27(2), 344-62. doi:10.1016/j.humov.2008.02.007.

Carrascosa Lezcano, A., Fernández García, J. M., Fernández Ramos, C., Ferrández Longás, A., López-Siguero, J. P., Sánchez González, E., ... Yeste Fernández, D. (2008). Estudio transversal español de crecimiento 2008. Parte II: valores de talla, peso e índice de masa corporal desde el nacimiento a la talla adulta. Anales de Pediatría, 68(6), 552-569. doi:10.1157/13123287.

deVinck-Baroody, O., Shui, A., Macklin, E.A., Hyman, S. L., Leventhal, J. M., \& Weitzman, C. (2015). Overweight and Obesity in a Sample of Children With Autism Spectrum Disorder.Academic Pediatrics, 15(4), 396-404. doi:10.1016/j.acap.2015.03.008.

Dickinson, K., \& Place, M. (2014). A Randomised Control Trial of the Impact of a Computer-Based Activity Programme upon the Fitness of Children with Autism. Autism Research and Treatment, 2014, 1-9. doi:10.1155/2014/419653.

Dreyer Gillette, M. L., Borner, K. B., Nadler, C. B., Poppert, K. M., Odar Stough, C., Swinburne Romine, R., \& Davis, A. M. (2015). Prevalence and health correlates of overweight and obesity in children with autism spectrum disorder. Journal of Developmental and Behavioral Pediatrics: JDBP, 36(7), 489-496. doi:10.1097/ DBP.0000000000000198.

Fernandez, J.R., Redden, D.T., Pietrobelli,A., Allison, D. (2004). Waist Circumference percentiles in Nationally representative samples of african american european american and mexican american children and adolescents. Pediatrics, 145(4), 439-444.

González-Gil, T., Mendoza-Soto, A., Alonso-Lloret, F., Castro-Murga, R., Pose-Becerra, C., \& Martín-Arribas, M. C. (2012). Versión española del cuestionario de calidad de vida para niños y adolescentes con cardiopatías (PedsQLTM). Revista Española de Cardiología, 65(3), 249-257. doi:10.1016/j.recesp.2011.10.010.

Kondric, M., Trajkovski, B., Strbad, M., Foretic, N., Zenic, N., Kondri, M., ... Zeni, N. (2013). Anthropometric influence on physical fitness among preschool children: gender-specific linear and curvilinear regression models. Collegium Antropologicum, 37(4), 1245-1252.

Lai, M.C., Lombardo, M.V.,Baron-Cohen, S. (2014). Autism. Lancet, 383, 896-910.

Latorre Román, P. Á., Mora López, D., Fernández Sánchez, M., Salas Sánchez, J., Moriana Coronas, F., \& García-Pinillos, F. (2015). Fiabilidad test-retest de una batería de evaluación de la condición físicomotora en niños de 3 a 6 años. Nutricion hospitalaria, 32(4), 1683-1688.

Lord, C., Risi, S., Lambrecht, L., Cook, E. H., Leventhal, B. L., DiLavore, P. C., ... Rutter, M. (2000). Autism Diagnostic Observation Schedule (ADOS). Journal of Autism and Developmental Disorders, 30(3), 205-223. doi:10.1007/BF02211841.

Lord, C., Rutter, M., \& Le Couteur, A. (1994). Autism Diagnostic Interview-Revised: Arevised version of a diagnostic interview for caregivers of individuals with possible pervasive developmental disorders. Journal of Autism and Developmental Disorders, 24(5), 659-685. doi:10.1007/BF02172145.

MacDonald, M., Lord, C., \& Ulrich, D. A. (2014). Motor skills and calibrated autism severity in young children with autism spectrum disorder.Adapted Physical Activity Quarterly/: APAQ, 31, 95-105. doi:10.1123/apaq.2013-0068.

Maffeis, C., Pietrobelli, A, Grezzani, A, Provera, S., \& Tatò, L. (2001).
Waist circumference and cardiovascular risk factors in prepubertal children. Obesity Research, 9(3), 179-187. doi:10.1038/ oby.2001.19.

Mazurek, M. O., \& Wenstrup, C. (2013). Television, video game and social media use among children with ASD and typically developing siblings. Journal of Autism and Developmental Disorders, 43, 12581271. doi:10.1007/s10803-012-1659-9.

Okely, A. D., Booth, M. L., \& Chey, T. (2004). Relationships between body composition and fundamental movement skills among children and adolescents. Research Quarterly for Exercise and Sport, 75 (March), 238-247. doi:10.1080/02701367.2004.10609157.

Ortega, F. B., Ruiz, J. R., Castillo, M. J., \& Sjöström, M. (2008). Physical fitness in childhood and adolescence: a powerful marker of health. International Journal ofObesity, 32(1), 1-11. doi:10.1038/ sj.ijo.0803774.

Pace, M., \& Bricout, V.-A. (2015). Low heart rate response of children with autism spectrum disorders in comparison to controls during physical exercise. Physiology \& Behavior, 141, 63-68. doi:10.1016/ j.physbeh.2015.01.011.

Pan, C. Y. (2011). The efficacy of an aquatic program on physical fitness and aquatic skills in children with and without autism spectrum disorders. Research in Autism Spectrum Disorders, 5, 657-665. doi:10.1016/j.rasd.2010.08.001.

Provost, B., Lopez, B. R., \& Heimerl, S. (2007). A comparison of motor delays in young children: Autism spectrum disorder, developmental delay, and developmental concerns. Journal of Autism and Developmental Disorders, 37(2), 321-328. doi:10.1007/ s10803-006-0170-6.

Rauner, A., Mess, F., \& Woll, A. (2013). The relationship between physical activity, physical fitness and overweight in adolescents: a systematic review of studies published in or after 2000. BMC Pediatrics, 13, 19. doi:10.1186/1471-2431-13-19.

Sandt, D. R., \& Frey, G C. (2005). Comparison of Physical Activity Levels Between Children With and Without Autistic Spectrum Disorders. Adapted Physical Activity Quarterly, 22(2), 146.

Serra Majem, L., Aranceta Bartronaq, J., Ribas Barba, L., Sangil Monroy, M., \& Pérez Rodrigo, C. (2003). El cribado del riesgo nutricional en pediatría. Validación del test rápido Krece Plus y resultados en la población española. Estudio enKid. (Masson, Ed.) (Barcelona). Sorensen, C., \& Zarrett, N. (2014). Benefits of Physical Activity for Adolescents with Autism Spectrum Disorders: A Comprehensive Review. Review Journal of Autism and Developmental Disorders, 1(4), 344-353. doi:10.1007/s40489-014-0027-4.

Staples, K. L., \& Reid, G. (2010). Fundamental movement skills and autism spectrum disorders. Journal of Autism and Developmental Disorders, 40(2), 209-217. doi:10.1007/s10803-009-0854-9.

Tanaka, C., Hikihara, Y., Ohkawara, K., \& Tanaka, S. (2012). Locomotive and non-locomotive activity as determined by triaxial accelerometry and physical fitness in Japanese preschool children. Pediatric Exercise Science, 24, 420-34.

Tyler, K., MacDonald, M., \& Menear, K. (2014). Physical Activity and Physical Fitness of School-Aged Children and Youth with Autism Spectrum Disorders. Autism Research and Treatment, 2014, 1-6. doi:10.1155/2014/312163.

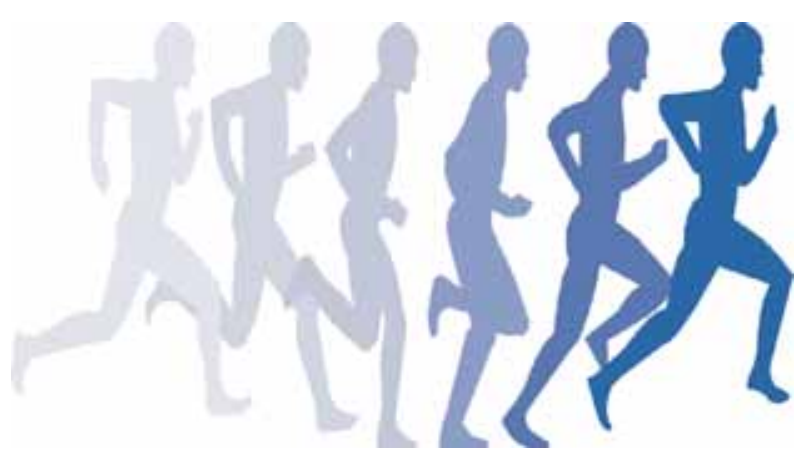

